\title{
Krzysztof Biegun*
}

Uniwersytet Ekonomiczny we Wrocławiu

\section{OCENA STABILIZACYJNEJ ROLI ZMIAN KURSU WALUTOWEGO W POLSCE W KONTEKŚCIE POTENCJALNEGO CZŁONKOSTWA W STREFIE EURO}

\section{STRESZCZENIE}

Kształtowanie mechanizmu kursowego jest uważane za jeden z najważniejszych instrumentów polityki gospodarczej. Celem niniejszego opracowania jest próba oceny stabilizacyjnej roli zmian kursu walutowego w Polsce w perspektywie członkostwa w trzecim etapie integracji gospodarczej i walutowej. Analiza została ograniczona do pary EUR/PLN. Zmiany realnego kursu walutowego EUR/PLN nie mogą być w zadowalającym stopniu wyjaśnione różnicami w sposobie przebiegu cykli koniunkturalnych obu gospodarek. Kurs walutowy był więc nie tylko instrumentem łagodzenia cyklu koniunkturalnego w reakcji na szoki, ale też sam był źródłem szoków nominalnych. Rezygnacja z instrumentu kursu walutowego będzie się więc wiązała z ograniczonym ryzykiem.

Slowa kluczowe: kurs walutowy, strefa euro, polityka kursu walutowego, unia walutowa

\section{Wprowadzenie}

Kształtowanie mechanizmu kursowego jest postrzegane jako jeden $\mathrm{z}$ najważniejszych instrumentów polityki gospodarczej. Podmioty odpowiedzialne za jej realizację starają się wpływać na cenę waluty krajowej w różnych sytuacjach,

\footnotetext{
*Adres e-mail:krzysztof.biegun@ue.wroc.pl.
} 
m.in. w celu osiągnięcia równowagi bilansu płatniczego, pobudzenia eksportu czy ograniczania inflacji. W literaturze przedmiotu znajdujemy wiele przykładów takich oddziaływań, coraz częściej jednak pojawiają się także głosy podważające skuteczność i ekonomiczną efektywność interwencji państwa na rynku walutowym.

Od momentu przystąpienia do UE polityka kursowa w Polsce była podporządkowana celowi strategicznemu, za jaki uznano pełne uczestnictwo w unii gospodarczej i walutowej oraz przyjęcie wspólnej waluty - euro.

Celem niniejszego opracowania jest próba oceny stabilizacyjnej roli zmian kursu walutowego w Polsce w perspektywie członkostwa w trzecim etapie integracji gospodarczej i walutowej. Analiza koncentruje się na parze EUR/PLN. Jest to podstawowa para walutowa na międzybankowym rynku złotego, najlepiej informująca o wartości waluty krajowej. Operacje wymiany EUR/PLN między podmiotami finansowymi dominują wśród kasowych operacji wymiany złotego. W transakcjach z podmiotami niefinansowymi udział transakcji EUR/PLN wynosi około $62 \%$ i w przybliżeniu odzwierciedla strukturę płatności w handlu międzynarodowym Polski. Badaniu poddano również nominalny (NEER) i realny (REER) efektywny kurs walutowy względem 17 krajów strefy euro. Ograniczenie badania efektywnych kursów do tak zdefiniowanej grupy państw wynika z dążenia do wyjaśnienia stabilizacyjnej roli kursu walutowego w relacji Polska-strefa euro. Rozstrzygnięcie dylematu, czy dla danej gospodarki płynny kurs walutowy jest mechanizmem przywracającym równowagę po wstrząsach makroekonomicznych czy też raczej źródłem takich wstrząsów, jest kluczowe dla bilansu kosztów i korzyści ewentualnego pełnego uczestnictwa w unii monetarnej. W związku z powyższym, przyjętym okresem badawczym są lata 2000-2011¹.

\section{Polityka kursowa w Polsce i jej determinanty}

Niezależnie od teoretycznej dyskusji nad kryteriami wyboru optymalnej polityki kursowej dla danego kraju w rozpatrywanym okresie, trzeba zauważyć, że w praktyce fundamentalną analizę kosztów i korzyści często zastępuje chęć osią-

${ }^{1}$ Analizę ograniczono do okresu, w którym kurs PLN był całkowicie płynny (free loat), a NBP w zasadzie nie podejmował interwencji na rynku walutowym. Od września 2011 r. NBP (sam lub wspólnie z BGK) podejmował interwencje na rynku walutowym nawet kilka do kilkunastu razy w ciągu roku. Data i skala każdej z interwencji pozostają zazwyczaj niejawne, nie ma więc możliwości oceny ich efektów. W okresie 2000-2011 NBP podjął zaledwie 1 interwencję na kursie PLN (w kwietniu 2010 r.). 
gnięcia krótkoterminowych korzyści związanych chociażby z ograniczeniem inflacji, pozyskaniem kapitału zagranicznego czy po prostu zwiększeniem wiarygodności w oczach inwestorów.

Doskonałym przykładem jest tutaj polityka kursowa Polski w procesie integracji ze strefą euro. W latach 1989-2000 Polska przeszła od kursu całkowicie sztywnego względem dolara amerykańskiego do niezależnego kursu płynnego, deklarując jednocześnie, że „kiedy tylko będzie to możliwe”, przejdzie do pełnego członkostwa w Europejskiej Unii Gospodarczej i Walutowej, co będzie oznaczało rezygnację z własnej waluty i przyjęcie euro. Wśród argumentów, które miały wpływ na decyzję o upłynnieniu kursu złotego, wymienić warto:

- nieefektywność dotychczasowych rozwiązań w przypadku większych przepływów kapitałowych, które prowadziły do znaczących zmian w podaży pieniądza rezerwowego i konieczności przeprowadzania operacji otwartego rynku na nadmierną skalę, co zwiększało koszty działalności NBP,

- wprowadzenie przez NBP strategii bezpośredniego celu inflacyjnego wymagało uelastycznienia systemu kursowego - narzucony zakres zmienności kursu walutowego mógł, w pewnych warunkach, obniżać skuteczność narzędzi polityki pieniężnej,

- dążenie do urealnienia kursu złotego względem euro przed planowanym przystąpieniem Polski do unii walutowej,

- chęć ograniczenia spekulacji na kursie złotego.

W związku z powyższym, w kwietniu 2000 roku Rada Polityki Pieniężnej we współpracy z Radą Ministrów podjęła decyzję o likwidacji granic dopuszczalnych wahań kursu złotego i całkowitym upłynnieniu tego kursu. Zrealizowano w ten sposób założenia „Średniookresowej strategii polityki pieniężnej” przyjętej w 1998 roku.

Od momentu upłynnienia kursu złotego jego kurs względem euro ulegał znaczącym wahaniom. Przez pierwszy rok złoty znajdował się w silnym trendzie wzrostowym. Cena euro spadła z 4,1 zł w czerwcu 2000 do 3,3 zł w czerwcu 2001 roku. W lipcu 2001 roku nastąpiło pierwsze załamanie kursu złotego, wywołane ujawnieniem przez Ministra Finansów prognoz dotyczących wielkości deficytu budżetowego i ograniczonych możliwości jego finansowania. Równolegle miał miejsce kryzys w Argentynie, który obniżył zaufanie inwestorów do krajów rozwijających się (do których podmioty rynku finansowego zaliczają również Polskę). W ciągu niespełna dwóch miesięcy cena euro wzrosła do ok. 3,9 zł. 
Rysunek 1. Średni kwartalny kurs EUR wyrażony w PLN w okresie Q1.2000-Q2.2011

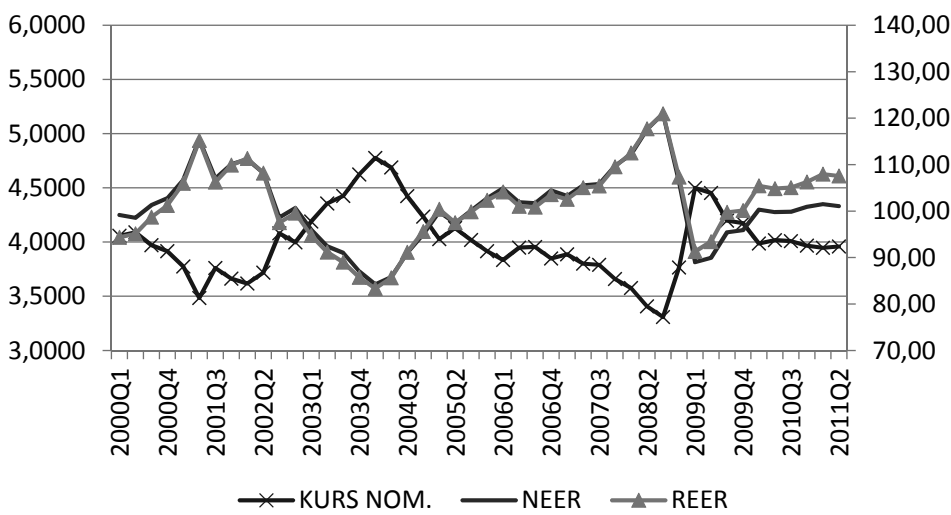

Kurs nominalny - lewa oś, kursy NEER i REER względem EA17 - prawa oś (indeks, 2005 = 100).

Źródło: opracowanie własne na podstawie danych NBP.

Drugi i trzeci okres znaczącego osłabienia złotego względem euro miały związek z bilateralnymi dostosowaniami kursu euro do dolara amerykańskiego. Pierwsza fala spadkowa (lato 2002) doprowadziła do wzrostu ceny euro z 3,5 do 4,1 zł. Trzecia fala, która rozpoczęła się w 2003 roku, zbiegła się w czasie z poważnymi napięciami na rynku walutowym Węgier. Kurs złotego dodatkowo osłabiły niepewność co do kondycji finansów publicznych i prognozy dotyczące potrzeb pożyczkowych.

Tabela 1. Szoki powodujące deprecjację złotego względem euro w latach 1997-2011

\begin{tabular}{|c|c|}
\hline Okres & Przyczyna zakłóceń \\
\hline 1 & 2 \\
\hline Maj 1997 & „kryzys czeski”, osłabienie złotego o 1,5\% w 1 dzień \\
\hline Lipiec 1997 & „kryzys powodziowy” osłabienie złotego o 5\% w 1 dzień \\
\hline Październik 1997 & „kryzys azjatycki” \\
\hline Maj 1998 & „kryzys indonezyjski” \\
\hline Sierpień 1998 & „kryzys rosyjski”, osłabienie złotego o $8 \%$ w ciągu 3 dni \\
\hline Styczeń 1999 & „,kryzys brazylijski” \\
\hline Listopad 1999 & $\begin{array}{l}\text { kryzys wewnętrzny - niejasna sytuacja budżetu, utworzenie rachunku waluto- } \\
\text { wego w NBP }\end{array}$ \\
\hline Kwiecień 2000 & „kryzys bilansu płatniczego” \\
\hline Lipiec 2001 & $\begin{array}{l}\text { „kryzys argentyński” + niepewna sytuacja budżetowa, osłabienie złotego } \\
\text { o } 14 \% \text { w } 4 \text { dni }\end{array}$ \\
\hline
\end{tabular}




\begin{tabular}{|l|l|}
\hline \multicolumn{1}{|c|}{1} & \multicolumn{1}{c|}{ 2 } \\
\hline Lipiec 2002 & ataki polityków na RPP; dymisja wicepremiera Belki \\
\hline Styczeń 2003 & „kryzys węgierski” \\
\hline Wrzesień 2003 & spadek zaufania do złotego w wyniku niepewności co do sytuacji budżetu \\
\hline Marzec 2005 & $\begin{array}{l}\text { Rada Europejska zdecydowała, że koszty reformy emerytalnej będą mogły } \\
\text { być odliczane od deficytu budżetowego tylko przez określony czas }\end{array}$ \\
\hline Maj 2006 & wzrost stóp procentowych w USA i strefie euro \\
\hline $\begin{array}{l}\text { Lipiec 2008 - marzec } \\
2009\end{array}$ & $\begin{array}{l}\text { gwałtowna deprecjacja złotego w wyniku kryzysu finansowego, marzec 2009 } \\
\text { - interwencja rządu w obronie kursu złotego (Bank Gospodarstwa Krajo- } \\
\text { wego dokonał sprzedaży znacznej ilości euro z rachunku rządowego); była } \\
\text { to pierwsza oficjalna interwencja polskich władz na rynku walutowym od } \\
\text { 1998 r. }\end{array}$ \\
\hline $2010-$ & $\begin{array}{l}\text { deprecjacja złotego wywołana ,ucieczką” inwestorów do walut tzw. bezpiecz- } \\
\text { nych, spowodowaną niewypłacalnością Grecji i niepewnością co do kondycji } \\
\text { finansów publicznych innych krajów strefy euro - Irlandii, Hiszpanii, Włoch }\end{array}$ \\
\hline
\end{tabular}

Źródło: Jurek (2007), s. 27; Szczepańska, Sotomska-Krzysztofik (2003), s. 16.

Od roku 2004 do czerwca 2008 roku złoty umacniał się względem euro. Przystąpienie do UE, napływ inwestycji, szybkie tempo wzrostu gospodarczego i poziom stóp procentowych, znacząco wyższy niż w strefie euro, przyczyniły się do wzrostu zainteresowania polską walutą na rynkach finansowych.

Światowy kryzys finansowy i związany z nim wzrost awersji do ryzyka spowodował jednak wycofywanie kapitału z rynków rozwijających się (do których jest przez inwestorów zaliczana Polska) spowodowały proces gwałtownej przeceny złotego od lipca 2008 roku. Kolejna znacząca przecena rozpoczęła się w 2010 roku w związku z tzw. kryzysem greckim.

Niezależnie od intencji władz, w gospodarce otwartej nie jest w praktyce możliwa pełna kontrola nad wszystkimi elementami polityki pieniężnej i kursowej. Prowadzenie autonomicznej polityki pieniężnej i utrzymywanie pełnej wymienialności waluty uniemożliwia kontrolę poziomu kursu walutowego. Z kolei utrzymywanie stałego poziomu kursu walutowego (przy zachowaniu wymienialności waluty) wymaga rezygnacji ze swobodnego kształtowania poziomu stóp procentowych przez bank centralny. Znacząca różnica w wysokości stóp procentowych pomiędzy wewnętrznym rynkiem kapitałowym a rynkiem kraju odniesienia spowodowałaby niekontrolowany przepływ kapitału spekulacyjnego. Utrzymanie pożądanego poziomu ceny waluty krajowej, przy jednoczesnym zachowaniu możliwości wykorzystywania stóp procentowych jako instrumentu polityki gospodarczej, wymaga z kolei ograniczenia wymienialności waluty (w pewnym stopniu przykładem zastosowania 
takiego wariantu jest gospodarka Chin). Polityka kursu walutowego nie powinna być więc rozpatrywana w oderwaniu od aktualnie prowadzonej polityki pieniężnej, jej celów i instrumentów. Trzeba także brać pod uwagę stopień wymienialności waluty, cele i kompetencje instytucji rynku pieniężnego i walutowego oraz zakres ich niezależności. Możliwe są zatem rozbieżności między deklarowaną polityką kursową a stanem faktycznym. Próbę ich wyjaśnienia znajdujemy m.in. w pracy H. Genberga i A. Swobody (2004, s. 4). Rozpatrują oni model dwóch państw o podobnej polityce pieniężnej (np. stosujących regułę Taylora dla krótkookresowych stóp procentowych). Zakładając wysoki stopień integracji rynków finansowych, podobne cele inflacyjne i zbieżność faz cyklu koniunkturalnego między tymi krajami, z dużą dozą prawdopodobieństwa dojdzie do znacznej konwergencji poziomu stóp procentowych. W efekcie można oczekiwać, że ich bilateralny kurs walutowy będzie względnie stały, mimo iż oba deklarują stosowanie niezależnego kursu płynnego.

Nie można zapominać również o politycznym aspekcie wyboru mechanizmu kursowego. Niezależnie od ekonomicznej analizy kosztów i korzyści przyjęcia konkretnego rozwiązania, w ostatecznym rozrachunku jest to zawsze decyzja polityczna, podejmowana przez partię rządzącą, dla osiągnięcia jej konkretnych celów. Ma więc (mniej lub bardziej bezpośrednio) służyć utrzymaniu władzy. W dyskusji, poza argumentami ekonomicznymi, pojawiają się też historyczne i ideologiczne, a waluta bywa traktowana jako symbol czy też czasem substytut niezawisłości. Nie przypadkiem decyzja o ustanowieniu własnej waluty była jedną z pierwszych decyzji władz byłych republik radzieckich w momencie ogłaszania przez nie niepodległości. Niestety, tak poważna kwestia, jak wybór mechanizmu kursowego, bywa też często wykorzystywana przez populistów do osiągania krótkoterminowych celów z całkowitym pominięciem opinii ekonomistów (lub nawet przeciw nim) czy też wbrew zdrowemu rozsądkowi. Ciekawe badania na temat tego, czy i w jaki sposób obowiązujący system polityczny determinuje wybory w ramach polityki kursowej, przeprowadził David A. Leblang (1998). Na podstawie danych z lat 1973-1994 dla 76 krajów rozwijających się, skonstruował model, który poza czynnikami ekonomicznymi uwzględniał m.in. takie zmienne, jak istnienie systemu wielopartyjnego, wolne wybory powszechne, oraz to, czy ordynacja wyborcza ma charakter większościowy czy reprezentatywny. Wyniki wskazują, że politycy w krajach demokratycznych muszą brać pod uwagę cykl wyborczy, a zdobycie i utrzymanie władzy wymaga od nich stosowania bardziej redystrybucyjnych i potencjalnie inflacjogennych 
instrumentów polityki gospodarczej. Tym samym politycy nie chcą być ograniczani w zakresie polityki monetarnej, częściej więc będą skłonni do wyboru płynnego mechanizmu kursu walutowego. Leblang stwierdził też znaczącą statystycznie różnicę między krajami o różnych typach demokracji. W krajach, w których wyniki wyborów ustalane są według ordynacji większościowej, władze częściej decydują się na sztywny mechanizm kursowy. Wynika to z faktu, iż częściej są to rządy jednopartyjne, które nie muszą swoich decyzji uzgadniać z koalicjantami. Najchętniej zaś systemy kursu sztywnego są stosowane przez rządy autorytarne. Wnioskom nie zaprzecza fakt, iż badania Leblanga zostały opublikowane w momencie, w którym kilkanaście demokratycznych państw Europy przygotowywało się do utworzenia unii walutowej, dotyczyły bowiem krajów rozwijających się, w których przed polityką gospodarczą stawia się nieco inne cele niż w krajach rozwiniętych.

\section{Stabilizacyjna rola zmian nominalnego i realnego kursu walutowego w Polsce}

Kurs walutowy może być wykorzystany do łagodzenia asymetrycznych wstrząsów popytowych. W przypadku innych szoków makroekonomicznych narzędzie to nie jest skuteczne (zob. tab. 2).

Tabela 2. Możliwość łagodzenia szoków popytowych i podażowych za pomocą zmian kursu walutowego

\begin{tabular}{|l|c|c|}
\hline & Szoki popytowe & Szoki podażowe \\
\hline Szoki symetryczne & nie & nie \\
\hline Szoki asymetryczne & tak & nie \\
\hline
\end{tabular}

Źródło: opracowanie własne.

Skuteczność dostosowania za pomocą zmian kursu walutowego zależy od czynników takich, jak np.:

- elastyczność cenowa i dochodowa eksportu i importu,

- elastyczność rynków pracy (zmniejsza ryzyko inflacji płacowej wynikającej z efektu inflacyjnego deprecjacji kursu walutowego) i rynków produktów (umożliwia dostosowanie podaży produkcji do struktury popytu zewnętrznego). 
Tabela 3. Średnioroczne zmiany kursu złotego polskiego w stosunku do ecu/euro a luka produktowa w Polsce w latach 2000-2011

\begin{tabular}{|c|c|c|c|c|c|}
\hline Rok & $\begin{array}{c}\text { Zmiany kursu } \\
\text { PLN wobec EUR } \\
\text { w stosunku do } \\
\text { poprzedniego roku } \\
\text { (w \%) }\end{array}$ & $\begin{array}{c}\text { Stopa inflacji } \\
\text { HICP }\end{array}$ & $\begin{array}{c}\text { Różnice w stopie } \\
\text { inflacji między } \\
\text { Polską a strefą } \\
\text { euro (w p.p.) }\end{array}$ & $\begin{array}{c}\text { Luka produk- } \\
\text { towa (w \% } \\
\text { potencjalnego } \\
\text { PKB) }\end{array}$ & $\begin{array}{c}\text { Różnice w luce pro- } \\
\text { duktowej między } \\
\text { Polską a strefą euro } \\
\text { (w \% potencjalnego } \\
\text { PKB) }\end{array}$ \\
\hline 2000 & 5,2 & 10,1 & 8,0 & 1,2 & $-1,0$ \\
\hline 2001 & 8,4 & 5,3 & 3,0 & $-0,3$ & $-2,2$ \\
\hline 2002 & $-5,0$ & 1,9 & $-0,3$ & $-1,8$ & $-2,6$ \\
\hline 2003 & $-14,1$ & 0,7 & $-1,4$ & $-1,1$ & $-0,7$ \\
\hline 2004 & $-2,9$ & 3,6 & 1,5 & 0,4 & 0,5 \\
\hline 2005 & 11,1 & 2,2 & 0,0 & $-0,2$ & $-0,1$ \\
\hline 2006 & 3,2 & 1,3 & $-0,9$ & 1,0 & $-0,3$ \\
\hline 2007 & 2,9 & 2,6 & 0,5 & 2,4 & $-0,1$ \\
\hline 2008 & 7,2 & 4,2 & 0,9 & 2,2 & 0,7 \\
\hline 2009 & $-18,8$ & 4,0 & 3,7 & $-0,7$ & 2,9 \\
\hline 2010 & 7,7 & 2,7 & 1,1 & $-0,8$ & 1,6 \\
\hline 2011 & $-3,2$ & 3,9 & 1,2 & $-0,2$ & 1,5 \\
\hline
\end{tabular}

Uwaga: komórki cieniowane - antycykliczne zmiany nominalnego kursy walutowego.

Źródło: opracowano na podstawie European Commission (2012a), s. 92-93; European Commission (2012b), s. 129.

Konkurencja cenowa pozostaje ważnym elementem strategii polskich przedsiębiorców na rynku europejskim (Jagiełło, Marczewski, Wysocka 2007, s. 72). W wyniku podejmowanych działań, niekorzystne zmiany kursowe przekładają się jednak raczej na wyniki finansowe (co jest efektem obniżania marży) oraz zatrudnienie i poziom wynagrodzeń w firmach eksportujących, niż w wolumen eksportu (Rosiek, 2008, s. 141-151).

Przeprowadzone badania empiryczne wskazują, że przez większość czasu zmiany nominalnego kursu PLN/ECU-EUR miały charakter antycykliczny, powinny więc przyczyniać się do łagodzenia cyklu koniunkturalnego w gospodarce polskiej (tab. 3). Jeżeli jednak pod uwagę weźmiemy nie tylko kurs nominalny, ale zmiany nominalnego i realnego efektywnego kursu walutowego, wnioski będą odmienne. 
Tabela 4. Zmiany nominalnego i realnego kursu walutowego w Polsce na tle warunków cyklicznych

\begin{tabular}{|c|c|c|c|c|c|}
\hline $\begin{array}{c}\text { Rok: } \\
\text { kwartał }\end{array}$ & $\begin{array}{c}\text { Zmiany indeksu } \\
\text { NEER vs. EA17 } \\
\text { (NEER } \\
\text { 1999=100) } \\
\text { w p.p. w stosun- } \\
\text { ku do poprzed- } \\
\text { niego kwartału }\end{array}$ & $\begin{array}{c}\text { Zmiany indeksu } \\
\text { REER (ULCE) } \\
\text { vs. EA 17 } \\
\text { (REER } \\
1999=100 \text { ) } \\
\text { w p.p. w stosun- } \\
\text { ku do poprzed- } \\
\text { niego kwartału }\end{array}$ & $\begin{array}{c}\text { Luka } \\
\text { produktowa } \\
\text { w \% trendu } \\
\text { PKB }\end{array}$ & $\begin{array}{c}\text { Zmiany luki } \\
\text { produktowej } \\
\text { w stosunku do } \\
\text { poprzedniego } \\
\text { kwartału } \\
\text { (w \% trendu } \\
\text { PKB) }\end{array}$ & $\begin{array}{l}\text { Różnica } \\
\text { w poziomie luki } \\
\text { produktowej } \\
\text { między Polską } \\
\text { a strefą euro } \\
\text { (w \% trendu } \\
\text { PKB) }\end{array}$ \\
\hline 1 & 2 & 3 & 4 & 5 & 6 \\
\hline $2000: 1$ & 6,64 & 7,41 & 1,86 & 0,51 & 0,49 \\
\hline $2000: 2$ & $-0,56$ & 0,47 & 1,91 & 0,05 & 0,19 \\
\hline $2000: 3$ & 2,97 & 4,57 & 1,67 & $-0,24$ & 0,09 \\
\hline 2000:4 & 1,60 & 3,56 & 1,29 & $-0,38$ & $-0,05$ \\
\hline 2001:1 & 4,06 & 6,15 & 0,92 & $-0,37$ & $-0,16$ \\
\hline 2001:2 & 9,20 & 11,21 & 0,56 & $-0,46$ & $-0,40$ \\
\hline $2001: 3$ & $-8,84$ & $-9,43$ & 0,16 & $-0,40$ & $-0,49$ \\
\hline 2001:4 & 3,23 & 2,48 & $-0,30$ & $-0,46$ & $-0,70$ \\
\hline 2002:1 & 1,14 & $-0,58$ & $-0,75$ & $-0,45$ & $-0,82$ \\
\hline 2002:2 & $-3,04$ & $-5,29$ & $-1,09$ & $-0,34$ & $-0,76$ \\
\hline $2002: 3$ & $-10,10$ & $-12,35$ & $-1,24$ & $-0,15$ & $-0,52$ \\
\hline 2002:4 & 2,15 & 0,62 & $-0,19$ & 1,05 & $-0,82$ \\
\hline 2003:1 & $-4,89$ & $-6,24$ & $-0,97$ & $-0,78$ & 0,18 \\
\hline $2003: 2$ & $-3,85$ & $-4,93$ & $-0,61$ & 0,36 & 0,55 \\
\hline $2003: 3$ & $-1,47$ & $-2,37$ & $-0,17$ & 0,44 & 0,93 \\
\hline 2003:4 & $-4,17$ & $-4,82$ & 0,28 & 0,45 & 1,34 \\
\hline $2004: 1$ & $-2,96$ & $-3,44$ & 0,59 & 0,31 & 1,69 \\
\hline $2004: 2$ & 1,15 & 1,20 & 0,66 & 0,07 & 1,88 \\
\hline 2004:3 & 5,42 & 4,99 & 0,42 & $-0,24$ & 1,79 \\
\hline 2004:4 & 4,20 & 3,98 & $-0,09$ & $-0,49$ & 1,34 \\
\hline $2005: 1$ & 5,08 & 4,89 & $-0,67$ & $-0,58$ & 0,63 \\
\hline $2005: 2$ & $-2,53$ & $-2,42$ & $-1,10$ & $-0,43$ & $-0,18$ \\
\hline $2005: 3$ & 2,82 & 2,54 & $-1,22$ & $-0,12$ & $-0,89$ \\
\hline $2005: 4$ & 2,81 & 2,31 & $-1,04$ & 0,18 & $-1,37$ \\
\hline 2006:1 & 2,24 & 1,70 & $-0,68$ & 0,36 & $-1,59$ \\
\hline 2006:2 & $-3,17$ & $-3,36$ & $-0,30$ & 0,38 & $-0,89$ \\
\hline 2006:3 & $-0,23$ & $-0,44$ & $-0,01$ & 0,29 & $-1,59$ \\
\hline 2006:4 & 2,92 & 2,77 & 0,23 & 0,24 & $-1,74$ \\
\hline $2007: 1$ & $-1,24$ & $-0,80$ & 0,52 & 0,29 & $-1,92$ \\
\hline $2007: 2$ & 2,40 & 3,09 & 0,94 & 0,42 & $-1,95$ \\
\hline 2007:3 & 0,33 & 1,65 & 1,46 & 0,52 & $-0,54$ \\
\hline $2007: 4$ & 4,09 & 5,71 & 1,90 & 0,44 & $-0,61$ \\
\hline
\end{tabular}




\begin{tabular}{|c|r|r|r|r|r|}
\hline 1 & 2 & 3 & 4 & 5 & 6 \\
\hline $2008: 1$ & 2,58 & 4,21 & 2,07 & 0,17 & 0,76 \\
\hline $2008: 2$ & 5,67 & 6,76 & 1,82 & $-0,25$ & 1,50 \\
\hline $2008: 3$ & 3,56 & 3,52 & 1,15 & $-0,67$ & 3,09 \\
\hline $2008: 4$ & $-15,47$ & $-16,53$ & 0,23 & $-0,92$ & 3,27 \\
\hline $2009: 1$ & $-18,13$ & $-19,15$ & $-0,66$ & $-0,89$ & 2,43 \\
\hline $2009: 2$ & 0,98 & 0,07 & $-1,29$ & $-0,63$ & 1,29 \\
\hline $2009: 3$ & 5,75 & 5,44 & $-1,56$ & $-0,27$ & 0,23 \\
\hline $2009: 4$ & 0,49 & 1,19 & $-1,49$ & 0,07 & 0,43 \\
\hline $2010: 1$ & 4,63 & 5,82 & $-1,27$ & 0,22 & $-0,70$ \\
\hline $2010: 2$ & $-0,57$ & 0,81 & $-1,00$ & 0,27 & $-0,84$ \\
\hline $2010: 3$ & 0,12 & 1,15 & $-0,73$ & 0,27 & $-0,68$ \\
\hline $2010: 4$ & 1,09 & 1,68 & $-0,48$ & 0,25 & $-0,59$ \\
\hline $2011: 1$ & 0,63 & 0,79 & $-0,22$ & 0,26 & $-0,42$ \\
\hline $2011: 2$ & $-0,47$ & $-0,43$ & 0,01 & 0,23 & $-0,18$ \\
\hline
\end{tabular}

Uwaga: NEER - nominalny efektywny kurs walutowy; REER (ULCE) - realny efektywny kurs walutowy oparty na nominalnych jednostkowych kosztach pracy w całej gospodarce. Interpretacja komórek cieniowanych: kolumna 2 - zmiany NEER jako główny czynnik zmian REER; kolumna 4 - zgodność kierunków zmian REER z dodatnim lub ujemnym poziomem luki produktowej; kolumna 5 - zmiany REER łagodzące wahania cykliczne; kolumna 6 zgodność zmian REER z różnicami w luce produktowej miedzy Polską a strefą euro.

Źródło: opracowano na podstawie danych tabeli oraz wskaźników konkurencyjności cenowej i kosztowej Komisji Europejskiej: http://ec.europa.eu/economy_finance/db_indicators/ competitiveness/documents/greea17.xls (30.03.2016).

W okresie Q1 2000-Q2 2011 r., zmiany NEER były silnie skorelowane ze zmianami REER (współczynnik korelacji 0,99). Z kolei współczynnik korelacji NEER z wielkością luki produktowej wyniósł zaledwie 0,24 , ze zmianą luki produktowej w stosunku do poprzedzającego kwartału 0,24 , zaś korelacja zmian NEER z różnicą w poziomie luki produktowej pomiędzy Polską a strefą euro była ujemna (wartość współczynnika korelacji-0,27). W przypadku zmian indeksu REER sytuacja wygląda podobnie. Zmiany realnego efektywnego kursu walutowego były słabo skorelowane z poziomem luki produktowej w Polsce (współczynnik korelacji 0,28) i jej zmianą w stosunku do poprzedzającego kwartału (współczynnik korelacji 0,22). Zmiany REER były słabo ujemnie skorelowane z różnicą luki produktowej w gospodarce Polski i strefy euro (współczynnik korelacji -0,27). Zmiany realnego efektywnego kursu złotego względem euro były więc silnie skorelowane ze zmianami kursu nominalnego, w niewielkim stopniu odzwierciedlały jednak zmienność cyklu koniunkturalnego w gospodarce polskiej. Zarówno NEER, jak i REER w niewielkim stopniu odzwierciedlały zmiany w różnicy luki produktowej pomiędzy Polską a strefą euro. 


\section{Podsumowanie}

Przystąpienie do strefy euro będzie oznaczało konieczność rezygnacji z możliwości realizacji autonomicznej polityki kursowej i wykorzystywania dewaluacji do wspierania konkurencyjności gospodarki krajowej. Wyniki przeprowadzonych badań wskazują, że nominalny efektywny kurs złotego względem euro był ściśle skorelowany z realnym, a znaczną część zmienności kursu nominalnego można wyjaśnić właśnie reakcją na szoki makroekonomiczne. Rezygnacja $z$ własnej waluty może więc spowodować wzrost zmienności poziomu produkcji. Z drugiej strony, znaczne wahania poziomu kursu nominalnego, jakie obserwowaliśmy w ostatnich latach, same w sobie były źródłem szoków nominalnych.

Zmiany realnego kursu walutowego EUR/PLN nie mogą być w zadowalającym stopniu wyjaśnione różnicami w sposobie przebiegu cykli koniunkturalnych obu gospodarek. Prowadzi to do wniosku, że w analizowanym okresie zmiany realnego kursu walutowego, determinujące konkurencyjność gospodarki, nie wynikały ze zmian czynników fundamentalnych, a były efektem innych wydarzeń mających wpływ na sytuację na rynku walutowym (np. zmian skłonności do ryzyka wśród inwestorów w czasie kryzysu finansowego). Kurs walutowy był więc nie tylko instrumentem łagodzenia cyklu koniunkturalnego w reakcji na szoki, ale też sam był źródłem szoków nominalnych. Rezygnacja $\mathrm{z}$ instrumentu kursu walutowego będzie się więc wiązała z ograniczonym ryzykiem.

Co więcej, w niemal całym okresie członkostwa Polski w UE, polityka kursowa nie była aktywnie wykorzystywana. Od czasu upłynnienia złotego w 2000 roku, aż do wiosny 2010 roku, NBP nie dokonywał interwencji na kursie złotego, a o cenie polskiej waluty decydowały wyłącznie czynniki rynkowe. Kurs złotego wobec głównych walut (w tym względem euro), podlegał znaczącym wahaniom, których, jak wykazały badania, nie można w satysfakcjonujący sposób wyjaśnić ani różnicami w poziomie inflacji pomiędzy Polską i strefą euro, ani zmianami luki produktowej. Rynkowy kurs złotego miał tendencję do znacznych odchyleń od tzw. kursu równowagi, obliczanego przez NBP. Od roku 2010 NBP dokonał kilku interwencji na kursie złotego, w większości o charakterze technicznym, jednak ze względu na fakt, iż nie podano do publicznej wiadomości celów, jakie te działania miały osiągnąć, ani wysokości transakcji, nie jest możliwa jednoznaczna ocena ich skutecz- 
ności. Rezygnacja z możliwości wykorzystania polityki kursowej do stabilizowania polskiej gospodarki po wystąpieniu szoku jest więc w praktyce rezygnacją z instrumentu, który w przeszłości był wykorzystywany jedynie w niewielkim stopniu.

\section{Literatura}

European Commission (2012a). Cyclical Adjustment Budget Balances, Spring. http:// ec.europa.eu/economy_finance/db_indicators/gen_gov_data/adjustment/index_en.htm (20.08.2016).

European Commission (2012b). Statistical Annex of European Economy, Spring. http:// ec.europa.eu/economy_finance/db_indicators/gen_gov_data/adjustment/index_en.htm (20.08.2016).

Genberg, H., Swoboda, A. (2004). Exchange-Rate Regimes: Does What Countries Say Matter? Geneva: Graduate Institute of International Studies.

Jagiełło M.E., Marczewski K., Wysocka A. (2007). Aktywność eksportowa polskich przedsiębiorstw przemystowych - wyniki badań ankietowych. Warszawa: Instytut Badań Rynku, Konsumpcji i Koniunktur.

Jurek, M. (2007). Dostosowanie polskiego systemu kursowego do zasad mechanizmu kursowego do ERM II. Bank i Kredyt, 5, 15-35.

Leblang, D.A. (1999). Domestic Political Institutions and Exchange Rate Commitments in the Developing World. International Studies Quarterly, 43 (4), 599-620.

Rosiek, J. (2008). Bariery rozwojowe polskiego eksportu do Unii Europejskiej a możliwości ich skutecznego ograniczania. Pobrano z: http://www.mikroekonomia.net/system/publication_files/229/original/12.pdf?1314889022 (26.08.2016).

Szczepańska, O., Sotomska-Krzysztofik, P. (2003). Reżim kursowy a kryzysy walutowe: czy możliwy jest kryzys w warunkach kursu płynnego? Bank i Kredyt, 9, 4-18. 


\title{
EVALUATION OF STABILIZING ROLE OF EXCHANGE RATE CHANGES IN POLAND IN THE CONTEXT OF POTENTIAL MEMBERSHIP IN THE EURO AREA
}

\begin{abstract}
The purpose of this paper is to assess the role of stabilizing the exchange rate changes in the membership of Poland in the third stage of economic and monetary integration. The analysis was limited to a pair EUR / PLN. Changes in the real exchange rate of EUR / PLN can't be to a satisfactory degree explained by differences in business cycles in both economies. The exchange rate was not only an instrument alleviating the business cycle in response to shocks, but also he was the source of nominal shocks. Therefore resignation from the exchange rate instrument will be associated with limited risk.
\end{abstract}

Translated by Krzysztof Biegun

Keywords: exchange rate, euro zone, exchange rate policy, monetary union

JEL codes: E42, E58, E65 